\title{
Analisis Kesalahan Siswa dalam Menyelesaikan Soal Pada Materi SPLDV Ditinjau dari Indikator Kemampuan Matematis
}

\author{
Ferry Ferdianto \\ Program Studi Pendidikan Matematika, Universitas Swadaya Gunung Jati, Cirebon, Indonesia \\ ferryunswagati@gmail.com \\ Leonardus Yesino* \\ Program Studi Pendidikan Matematika, Universitas Swadaya Gunung Jati, Cirebon, Indonesia \\ *Penulis Korespondensi, leonardusyesino@yahoo.co.id
}

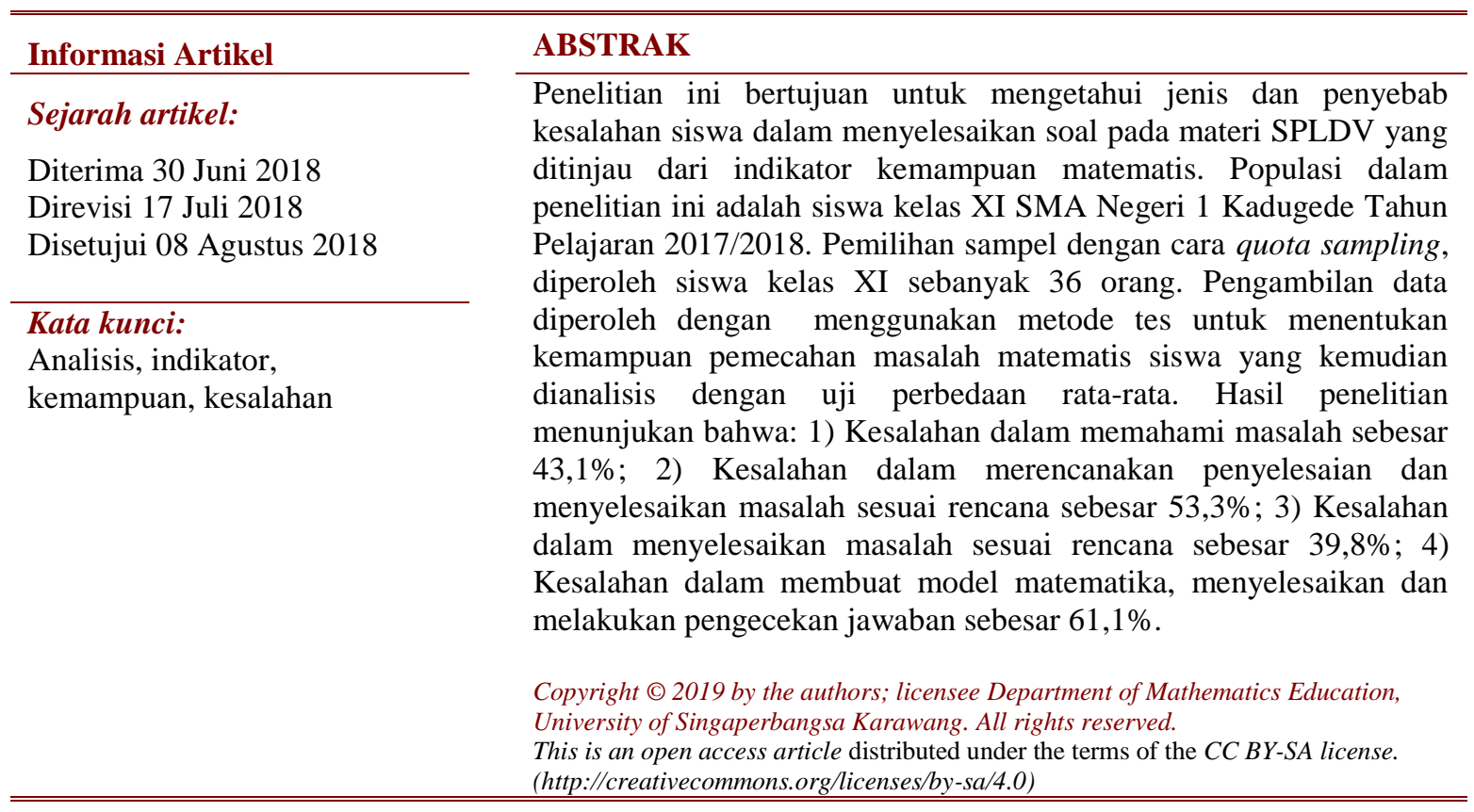

\section{PENDAHULUAN}

Pendidikan didefinisikan sebagai upaya memanusiakan manusia muda atau pengangkatan manusia muda ke taraf insani (Driyarkara, 1980). Pendidikan sangat penting untuk dikembangkan dalam berbagai ilmu pengetahuan. Pendidikan mempunyai fungsi tersendiri dalam mempersiapkan generasi bangsa mendukung pertumbuhan ekonomi bangsa. Pendidikan mempunyai empat macam fungsi, yaitu: 1) Transmisi Kultural 2) Memilih dan Mengajarkan Peranan Sosial 3) Menjamin Integrasi Sosial 4) Mengadakan Inovasi-inovasi Sosial (Syafi'i, 1991).

Tujuan pendidikan nasional adalah mengembangkan potensi peserta didik agar menjadi manusia yang beriman dan bertakwa kepada Tuhan Yang Maha Esa, berakhlak mulia, sehat, berilmu, cakap, kreatif, mandiri, dan menjadi warga negara yang demokratis serta bertanggung jawab (Depdiknas, 2003). Tujuan pendidikan nasional tersebut meliputi berbagai disiplin ilmu, satu diantaranya pada pelajaran matematika.

Dalam kehidupan sehari-hari manusia sering dihadapkan pada masalahmasalah yang menuntut untuk diselesaikan, hal ini tidak terlepas dari pelajaran matematika. Kenyataannya matematika kurang disukai dan dikuasai oleh kebanyakan siswa (Ferdianto, 
2015). Matematika adalah suatu disiplin ilmu berupa pemikiran dan prosedur pengolahan logika secara kuantitatif maupun kualitatif yang memiliki objek tujuan abstrak, bertumpu pada kesepakatan dan berpola pikir deduktif (Suherman, 2003; Soejadi, 2000). Matematika sangat penting bagi ilmu pengetahuan, terutama dalam peran yang dimainkannya dalam mengekspresikan model ilmiah (Wahyuni, 2013). Tanpa matematika maka pengetahuan akan berhenti pada tahap kualitatif yang tidak memungkinkan seseorang untuk meningkatkan penalaran lebih jauh. Oleh karena itu, dapat dikatakan bahwa ilmu tanpa matematika tidak berkembang dan hampir semua bidang kehidupan menggunakan jasa matematika, diantaranya: teknologi industri, perbankan, komunikasi, komputer, perdagangan, pertahanan dan keamanan, bahkan sosial politik. Matematika merupakan ilmu yang dibutuhkan berbagai bidang, baik dalam matematika itu sendiri maupun dalam bidang-bidang yang lain (Purwosusilo, 2014).

Berdasarkan hasil pengamatan penulis ditemukan bahwa banyak siswa yang mengalami hambatan saat belajar dan beranggapan matematika merupakan pelajaran yang sulit dan membosankan sehingga prestasi hasil belajar siswa tidak sesuai dengan yang mereka inginkan. Dalam mempelajari ilmu matematika siswa tidak hanya diajarkan untuk menghafal rumus-rumus matematika saja, melainkan siswa juga harus bisa menggunakan ilmu matematika untuk mengkomunikasikan supaya pemahamannya dapat dimengerti orang lain (Saifiyah, 2017). Penelitian ini bertujuan untuk mengetahui jenis dan penyebab kesalahan siswa dalam menyelesaikan soal pada materi SPLDV yang ditinjau dari indikator kemampuan matematis.

\section{METODE}

Penelitian ini adalah penelitian kuantitatif. Penelitian kuantitatif adalah penelitian yang menggunakan proses data-data yang dilakukan dengan kajian pemikiran yang sifatnya ilmiah, berupa angka sebagai alat menganalisis dan melakukan kajian penelitian terutama mengenai apa yang sudah diteliti (Kasiram, 2008; Suriasumantri, 2005). Metode penelitian ini berlandaskan pada filsafat postositivisme, digunakan untuk meneliti kondisi objek yang alamiah, peneliti sebagai instrumen. Teknik pengambilan data dilakukan melalui tahap observasi, tes dan studi dokumen. Analisis data sesuai dengan Analisis Miles \& Huberman, yaitu: reduksi data, penyajian data dan penarikan kesimpulan. Hasil penelitian kualitatif lebih menekankan makna daripada generalisasi (Sugiyono, 2013). Subjek dari penelitian ini adalah siswa kelas XI SMA Negeri 1 Kadugede. Data penelitian ini adalah data hasil tes kognitif siswa, berupa uraian dari soal Sistem Persamaan Linear Dua Variabel (SPLDV) yang ditinjau dari indikator kemampuan matematis.

Tabel 1. Statistik Deksriptif Nilai Siswa Pada Mata Pelajaran Sistem Persamaan Linear Dua Variabel (SPLDV)

\begin{tabular}{lccccc}
\hline & $\mathrm{N}$ & Minimum & Maximum & Mean & Std. Deviation \\
\hline Nilai_Siswa & 36 & 15 & 95 & 50,50 & 20,632 \\
$\begin{array}{l}\text { Valid N } \\
\text { (listwise) }\end{array}$ & 36 & & & & \\
\hline
\end{tabular}

Berdasarkan Tabel 1 didapat nilai minimum sebesar 15, nilai maksimum sebesar 95, rata-rata sebesar 50,50 dan standar deviasi 20,632. 


\section{HASIL DAN PEMBAHASAN}

Tes diberikan setelah materi sudah diberikan kepada siswa, berdasarkan hasil jawaban siswa dalam mengerjakan soal-soal pada materi Sistem Persamaan Linear Dua Variabel (SPLDV) tersebut, terdapat beberapa kesalahan yang dilakukan oleh beberapa siswa. Berikut tabel perhitungan persentase analisis kesalahan siswa.

Tabel 2. Persentase Kesalahan Siswa

\begin{tabular}{lcc}
\hline \multicolumn{1}{c}{ Indikator } & $\begin{array}{c}\text { Persentase } \\
\text { Jawaban Benar }\end{array}$ & $\begin{array}{c}\text { Persentase } \\
\text { Jawaban Salah }\end{array}$ \\
\hline $\begin{array}{l}\text { Memahami Masalah } \\
\text { Merencanakan Penyelesaian dan Menyelesaikan }\end{array}$ & $56,9 \%$ & $43,1 \%$ \\
$\begin{array}{l}\text { Masalah Sesuai Rencana } \\
\text { Menyelesaikan Masalah Sesuai Rencana }\end{array}$ & $53,3 \%$ \\
$\begin{array}{l}\text { Membuat Model Matematika, Menyelesaikan dan } \\
\text { Melakukan Pengecekan Jawaban }\end{array}$ & $38,9 \%$ & $39,8 \%$ \\
\hline
\end{tabular}

Data Kemampuan Siswa Kelas XI MIPA 4 Pada Materi SPLDV

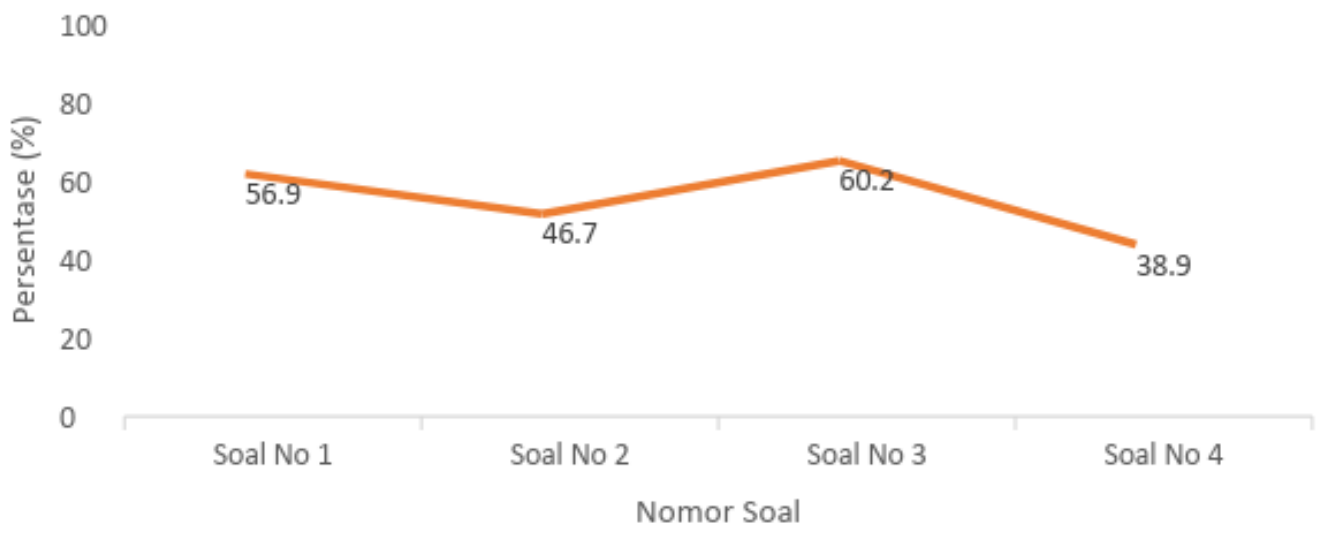

Gambar 1. Grafik Kesalahan Siswa dalam Mengerjakan Soal

Dari Gambar 1 diatas diketahui persentase kesalahan siswa dalam memahami masalah sebesar $43,1 \%$, persentase kesalahan siswa dalam merencanakan penyelesaian dan menyelesaikan masalah sesuai rencana sebesar 53,3\%, persentase kesalahan siswa dalam menyelesaikan masalah sesuai rencana sebesar 39,8\% dan persentase kesalahan siswa dalam membuat model matematika, menyelesaikan dan melakukan pengecekan jawaban sebesar $61,1 \%$.

Berikut penjabaran dari kesalahan-kesalahan siswa diatas:

a. Kesalahan siswa dalam memahami soal dan mengubah bentuk soal tersebut ke dalam model matematika.

b. Kesalahan siswa dalam membuat grafik dari model matematika yang telah dibuat.

c. Kesalahan membuat kalimat matematika yaitu kesalahan siswa dalam memodelkan sebuah permasalahan yang telah diberikan.

d. Kesalahan menarik kesimpulan yaitu kesalahan siswa dalam menyimpulkan jawaban yang telah dikerjakan sebelumnya. 


\section{SIMPULAN}

Berdasarkan hasil penelitian dan pembahasan diatas, maka peneliti dapat menyimpulkan:

1. Kesalahan-kesalahan yang dilakukan siswa dalam menyelesaikan soal pada materi SPLDV yaitu:

e. Kesalahan siswa dalam memahami soal dan mengubah bentuk soal tersebut ke dalam model matematika.

f. Kesalahan siswa dalam membuat grafik dari model matematika yang telah dibuat.

g. Kesalahan membuat kalimat matematika yaitu kesalahan siswa dalam memodelkan sebuah permasalahan yang telah diberikan.

h. Kesalahan menarik kesimpulan yaitu kesalahan siswa dalam menyimpulkan jawaban yang telah dikerjakan sebelumnya.

2. Penyebab terjadinya kesalahan yang dilakukan siswa dalam menyelesaikan soal pada materi SPLDV yaitu:

a. Penyebab terjadinya kesalahan dalam mengorganisasikan data dan memodelkan data adalah masih terjadinya miskonsepsi pada soswa. Siswa masih pada tahap belajar, belum sampai pada tahap pemahaman maupun analisis.

b. Penyebab kesalahan dalam memodelkan sebuah permasalahan ini adalah siswa masih kurang berlatih soal. Jadi, ketika siswa diberikan permasalahan yang lebih baru dan belum pernah dikerjakan sebelumnya, ia merasa kesulitan dalam mengerjakan soal.

c. Penyebab dari kesalahan menarik sebuah kesimpulan ini adalah siswa tergesagesa dalam mengerjakan soal, sehingga fokus siswa terhadap apa yang dipikirkan sebelumnya dengan yang dituliskan setelahnya.

3. Persentase kesalahan yang dilakukan siswa dalam menyelesaikan soal pada materi SPLDV yaitu:

a. Kesalahan yang dilakukan siswa dalam memahami masalah sebesar $43,1 \%$.

b. Kesalahan yang dilakukan siswa dalam merencanakan penyelesaian dan menyelesaikan masalah sesuai rencana sebesar 53,3\%.

c. Kesalahan yang dilakukan siswa dalam menyelesaikan masalah sesuai rencana sebesar $39,8 \%$.

d. Kesalahan yang dilakukan siswa dalam membuat model matematika, menyelesaikan dan melakukan pengecekan jawaban sebesar $61,1 \%$.

\section{DAFTAR PUSTAKA}

Syafi'i, A.M. (1991). Pendidikan Islam di Indonesia antara Cita dan Fakta. Yogyakarta: PT. Tiara Wacana.

Depdiknas. (2003). Undang-Undang RI No. 20 tahun 2003 Tentang Sistem Pendidikan Nasional. Jakarta.

Driyarkara. (1980). Driyarkara Tentang Pendidikan. Yogyakarta: Yayasan Kanisius. 
Ferdianto., F. (2015). Media Audio Visual pada Kemampuan Komunikasi Matematis Siswa Kelas IX. Jurnal Euclid, 2(2), 251-365.

Kasiram. (2008). Metodologi Penelitian. Malang: UIN-Malang Pers.

Purwosusilo. (2014). Peningkatan Kemampuan Pemahaman dan Pemecahan Masalah Matematik Siswa SMK melalui Strategi Pembelajaran REACT. Jurnal Pendidikan Keguruan, 1(2).

Saifiyah. (2017). Desain Modul Pembelajaran Berbasis Kemampuan Komunikasi Matematis dan Motivasi Belajar Siswa. KALAMATIKA Jurnal Pendidikan Matematika. 2(2), 177-192.

Soejadi. (2000). Kiat Pendidikan Matematika di Indonesia. Jakarta: Direktorat Jendral Pendidikan Tinggi Departemen Pendidikan Nasional.

Sugiyono. (2013). Metode Penelitian Pendidikan Pendekatan Kuantitatif, Kualitatif dan $R$ $\& D$. Bandung: Alfabeta.

Suherman, E. (2003). Strategi Pembelajaran Matematika Kontemporer. Bandung: PT Remaja Rosdakarya.

Suriasumantri, J.S. (2005). Filsafat Ilmu: Sebuah Pengantar Populer. Jakarta: Pustaka Sinar Harapan.

Wahyuni. (2013). Penerapan Model Learning Cycle 7E untuk Meningkatkan Kemampuan Pemecahan Masalah Matematis Siswa SMA. Skripsi pada UPI Bandung: Tidak Diterbitkan.

\title{
Analysis of Student Errors in Solving the Problem on SPLDV Material in Terms of Indicators of Mathematical Ability
}

\author{
Ferry Ferdianto \\ Department of Mathematics Education, Universitas Swadaya Gunung Jati, Cirebon, Indonesia \\ ferryunswagati@gmail.com \\ Leonardus Yesino* \\ Department of Mathematics Education, Universitas Swadaya Gunung Jati, Cirebon, Indonesia \\ *Corresponding Author, leonardusyesino@yahoo.co.id
}

\begin{abstract}
This study aims to determine the type and causes of student error in solving the problem on SPLDV material that is reviewed from the indicators of mathematical ability. Population in this study were students of class XI SMA Negeri 1 Kadugede year lesson 2017/2018. Sample selection by way of quota sampling, obtained student class XI counted 36 people. Data retrieval was obtained by using the test method to determine the mathematical problem solving ability of student which then analyzed by test the difference of average. The results of study show that: 1) Error in understanding the problem of $43,1 \% ; 2$ ) Error in planning completion and solve the problem according to plan of 53,3\%; 3) Error in solving problem according to plan equal to $39,8 \%$; 4) Error in making mathematical model, completed and checked the answer of $61,1 \%$.
\end{abstract}

Keywords: Analysis, indicators, mathematical ability, student errors

Received June $30^{\text {th }}, 2018$

Revised July $17^{\text {th }}, 2018$

Accepted August $08^{\text {th }}, 2018$ 